\title{
Host Plant Resistance for Bruchids in Pre-breeding Lines of Greengram [Vigna radiata (L.) Wilczek]
}

\author{
G.P. Harshitha, P. Jayamani, S. Manimegalai ${ }^{1}$, A. Muthuswamy
}

$10.18805 /$ LR -4702

\begin{abstract}
Background: Bruchid beetle (Callosobruchus chinensis) is one of the devastating field carry over storage pest causing a huge crop loss, especially in greengram. The pre-breeding lines were developed by crossing between a cultivated variety, VBN (Gg) 2 and Vigna radiata var. sublobata, a progenitor species of greengram used as a resistant parent against bruchid.

Methods: A total of 53 stabilized inter sub-specific lines along with parents were screened for bruchid resistance by 'no choice' method with two replications. Screening parameters were recorded for all the 53 lines and were statistically analysed. Damage assessment was carried out and the three resistant lines obtained during initial screening was further confirmed.

Result: The low seed damage per cent was observed in three lines viz., GGISC-2 (18.00), GGISC-21 (20.00) and GGISC-49 (14.00). The susceptibility index was $0.048,0.049$ and 0.048 in GGISC-2, GGISC-21 and GGISC-49, respectively and hence, classified as bruchid resistant. Delayed adult emergence, uneven adult emergence, prolonged developmental period, small and malformed adults were the other parameters observed in resistant lines. The three resistant lines identified could be further utilized in the breeding programmes for the development of bruchid resistant varieties in greengram.
\end{abstract}

Key words: Bruchid resistance, Greengram, Inter sub-specific cross, Pre-breeding lines, Vigna radiata.

\section{INTRODUCTION}

Greengram (Vigna radiata) is being a short duration legume crop, can be grown in several cropping systems and also fits well into rice-wheat cropping system followed in IndoGangetic plains of India (Brar et al., 2004). Greengram is a rich source of digestible proteins comprising of major amino acids viz., lysine, arginine, histidine and tryptophan. Greengram seeds contains about 60-65 per cent carbohydrates, 22-28 per cent proteins, 3.5-5.0 per cent fibres and 1-1.5 per cent fat (Zaid et al., 2012). India is the largest producer of greengram, covering an area 4.25 million hectares with production of 2.01 million tones and productivity of $474 \mathrm{~kg} / \mathrm{ha}$ (Annual Report, DPD, 2017-18).

Bruchid beetle (Callosobruchus chinensis) is the field carry over storage pest causing a huge crop loss, especially in greengram. The bruchid infestation starts at the field as the bruchid adults lay eggs on the pods and when such pods are harvested and stored, the insect population increases enormously and leads to complete destruction in both quality and quantity of the seeds.

The economic loss due to bruchid in different pulse crops varies from 30 to 40 per cent within six months of storage period. If the damage is left unnoticed then the losses may go up to 100 per cent (Dongre et al., 1996). Effective chemical control measures are available for bruchid but they leave a residual effect on the seed which may affect the human health. In recent times emphasis is given towards the use of eco-friendly approaches to control the bruchid infestation. Development of resistant varieties against bruchids is the essential step towards the sustainable protection of stored grains. About 10 per cent of the greengram produced is lost due to Callosobruchus chinensis
Department of Pulses, Centre for Plant Breeding and Genetics, Tamil Nadu Agricultural University, Coimbatore-641 003, Tamil Nadu, India.

${ }^{1}$ Department of Sericulture, Forest College and Research Institute, Mettupalayam-641 301, Tamil Nadu, India.

Corresponding Author: P. Jayamani, Department of Pulses, Centre for Plant Breeding and Genetics, Tamil Nadu Agricultural University, Coimbatore-641 003, Tamil Nadu, India.

Email: jayamani1108@gmail.com

How to cite this article: Harshitha, G.P., Jayamani, P., Manimegalai, S. and Muthuswamy, A. (2022). Host Plant Resistance for Bruchids in Pre-breeding Lines of Greengram [Vigna radiata (L.) Wilczek]. Legume Research. DOI: 10.18805/LR-4702.

Submitted: 21-06-2021 Accepted: 18-01-2022 Online: 08-03-2022

during the storage period, Mookherjee et al. (1970) and Sutanu et al. (2015). High yielding greengram varieties are highly susceptible to bruchid infestation therefore the resistant genes present in the wild and primitive cultivars should be identified and transferred to the cultivated genotypes.

\section{MATERIALS AND METHODS}

The experimental material consisted of 53 stabilized inter sub-specific lines of greengram derived from VBN (Gg) 2 and Vigna radiata var. sublobata/2, a wild progenitor of greengram used as a resistant parent for bruchid infestation. The bruchid species used for screening was Callosobruchus chinensis. The stock culture of callosobruchus chinensis was maintained on greengram seeds. Screening was carried with 'No choice' method (Dongre et al., 1993) in two replications during 2019-20, in Department of Pulses, Centre for Plant 
Breeding and Genetics, Tamil Nadu Agricultural University, Coimbatore. Fifty equal sized seeds were selected from 53 lines of along with the parents viz., VBN $(\mathrm{Gg}) 2$ and Vigna radiata var. sublobata considered as susceptible and resistant checks, respectively. The selected seeds were transferred into Petriplates and five pairs of bruchids were released and maintained under controlled laboratory conditions. Standard screening parameters were recorded viz., initial seed weight (g), final seed weight (g), male bruchid weight (mg), female bruchid weight $(\mathrm{mg})$, total bruchid weight (mg) and adult emergence per cent. Damage assessment was carried out on $30^{\text {th }}$ day of inoculation by calculating weight loss per cent of seed (Khattak et al. (1987), susceptibility index (Howe, 1971) and seed damage per cent (Nagaraja, 2006). Independent screening was carried out for the resistant lines and parents for the confirmation of bruchid resistance. Based on the per cent seed damage, the lines were classified as highly resistant $(0-10 \%)$, resistant (10.1-20\%), moderately resistant $(20.1-40 \%)$, susceptible (40.1-80\%) and highly susceptible (80.1-100\%) (Mariyammal et al., 2019).

\section{RESULTS AND DISCUSSION}

Screening parameters were recorded for all the 53 inter subspecific lines of greengram along with parental lines. Wide range of initial seed weight indicated the presence of large variations among the lines. The range varied from 1.14 to $2.15 \mathrm{~g}$ for 50 seeds. Wild progenitor of greengram i.e. Vigna radiata var. sublobata recorded the initial weight of $0.65 \mathrm{~g}$ whereas, the female parent i.e. VBN $(\mathrm{Gg}) 2$ recorded the initial seed weight of $1.63 \mathrm{~g}$ (Table 1).

Final seed weight after adult emergence among 53 lines ranged from 0.67 to $1.18 \mathrm{~g}$. VBN $(\mathrm{Gg}) 2$ showed the highest reduction in the seed weight and recorded the final weight of $0.69 \mathrm{~g}$. Vigna radiata var. sublobata recorded less weight loss and recorded the final weight of $0.53 \mathrm{~g}$. Mei et al. (2009) also recorded least weight loss in Vigna radiata var. sublobata and revealed its importance in development of bruchid resistant genotypes of greengram.

Among 53 lines, three lines showed less weight loss and recorded final seed weight of $0.98 \mathrm{~g}$ (GGISC-2), $0.96 \mathrm{~g}$ (GGISC-21) and $1.18 \mathrm{~g}$ (GGISC-49). Final seed weight of above three lines and Vigna radiata var. sublobata recorded lesser weight loss than the other pre-breeding lines.

Weight of ten male and female bruchid beetle was recorded for all the 53 lines of greengram along with the parental lines. Maximum weight of male $(18.80 \mathrm{mg})$ and female bruchid $(26.55 \mathrm{mg}$ ) was recorded in VBN $(\mathrm{Gg}) 2$, cultivated parental line. The least weight of male and female bruchid was recorded by wild parent Vigna radiata var. sublobata (11.02 $\mathrm{mg}$ and $15.34 \mathrm{mg}$, respectively). Among 53 lines, three lines viz., GGISC-2, GGISC-21 and GGISC49 recorded malformed bruchids and also less bruchid weight compared to other lines (Table 1). In wild parent and in the above three lines, the adults were weak and malformed. The results revealed that the weight of the bruchid was less in resistant lines. Whereas, bruchid adults were well developed and weighed more in susceptible lines. Samyuktha et al. (2020) reported that the resistant genotypes expressed the antibiosis mechanism against bruchid infestation and caused the malformation and death of grub in greengram.

\section{Damage assessment parameters}

In the present study, damage assessment parameters viz., weight loss of the seed, seed damage and susceptibility index were worked out to categorize the greengram varieties into different classes based on the level of bruchid resistance.

Weight loss of seed ranged from 21.80 to 54.22 per cent among the 53 lines under study. Three lines recorded the lesser weight loss compared to all the other lines under screening viz., GGISC-49 (21.80 per cent), GGISC-2 (22.60 per cent) and GGISC-21 (23.90 per cent). The wild parent recorded the weight loss of 18.60 per cent and the cultivated parent [VBN $(\mathrm{Gg})$ 2] recorded the weight loss of 57.53 per cent (Table 1). This clearly indicates that the wild parent is more resistant than all the lines under study. Seram et al. (2016) reported low weight loss per cent in bruchid resistant genotypes of greengram.

Seed damage was less than twenty per cent in three inter sub-specific lines viz., GGISC-2 (18.00), GGISC-21 (20.00), GGISC-49 (14.00) and Vigna radiata var. sublobata (12.00), whereas, susceptible parent (VBN (Gg) 2) and resistant parent (Vigna radiata var. sublobata) reached 100 and 12 per cent adult emergence, respectively on $30^{\text {th }}$ day of screening. Soumia et al. (2017) reported that the reduction adult emergence is an indication of the presence of antinutritional factors in seed that results in the prolongation of developmental period of bruchid in greengram.

The range of susceptibility index varied from 0.048 (GGISC-2 and GGISC-49) to 0.068 (GGISC-6 and GGISC$52)$. Three lines recorded the susceptibility index less than 0.050 (resistant category) viz., GGISC-2 (0.048), GGISC-21 (0.049) and GGISC-49 (0.048). Among the parental lines, Vigna radiata var. sublobata recorded the susceptibility index of 0.044 i.e. it falls under resistant category whereas, VBN (Gg) 2 recorded the susceptibility index of 0.078 and showed susceptible reaction. Neupane et al. (2016) and Gosh et al. (2020) also used susceptibility index and weight loss per cent for determining the level of bruchid resistance in greengram. Samyuktha et al. (2020) screened VBN (Gg) 2 for bruchid resistance by using no choice method of screening and also used weight loss per cent and susceptibility index for assessing the resistance level and concluded that VBN $(\mathrm{Gg})$ 2 belongs to susceptible category. Sarkar and Bhattacharyya (2015) and Soumia et al. (2017) reported that the susceptibility index was more than 0.05 and seed damage was more than 40 per cent in susceptible varieties of greengram.

The categorization of inter sub-specific lines was carried out based on seed damage per cent on $30^{\text {th }}$ day of screening (cumulative) as the susceptible parent (VBN (Gg) 2) showed 100 per cent adult emergence on $30^{\text {th }}$ day. Whereas, Vigna radiata var. sublobata recorded only twelve per cent damage. 
Host Plant Resistance for Bruchids in Pre-breeding Lines of Greengram [Vigna radiata (L.) Wilczek]

Table 1: Bruchid screening of 53 inter sub-specific lines of greengram.

\begin{tabular}{|c|c|c|c|c|c|c|c|c|}
\hline Genotypes & $\begin{array}{l}\text { Initial seed } \\
\text { weight } \\
\text { (g) }\end{array}$ & $\begin{array}{c}\text { Final seed } \\
\text { weight } \\
\text { (g) }\end{array}$ & $\begin{array}{c}\text { Weight loss } \\
\text { per cent } \\
\text { of seed }\end{array}$ & $\begin{array}{c}\text { Male bruchid } \\
\text { weight } \\
(\mathrm{mg})\end{array}$ & $\begin{array}{c}\text { Female } \\
\text { bruchid weight } \\
(\mathrm{mg})\end{array}$ & $\begin{array}{c}\text { Total bruchid } \\
\text { weight } \\
(\mathrm{mg})\end{array}$ & $\begin{array}{l}\text { Seed damage } \\
\text { per cent } \\
\text { on } 30^{\text {th }} \text { day }\end{array}$ & $\begin{array}{c}\text { Susceptibility } \\
\text { index }\end{array}$ \\
\hline GGISC-1 & 1.60 & 0.87 & 45.70 & 14.75 & 21.55 & 36.30 & 64.00 & 0.066 \\
\hline GGISC-2 & 1.22 & 0.98 & 22.60 & 12.40 & 18.62 & 31.02 & 18.00 & 0.048 \\
\hline GGISC-3 & 1.52 & 0.81 & 46.90 & 16.45 & 24.00 & 40.45 & 65.30 & 0.066 \\
\hline GGISC-4 & 1.39 & 0.79 & 42.89 & 13.90 & 23.45 & 37.35 & 34.00 & 0.057 \\
\hline GGISC-5 & 1.53 & 0.87 & 43.06 & 14.00 & 21.20 & 35.20 & 62.50 & 0.065 \\
\hline GGISC-6 & 1.50 & 0.84 & 44.07 & 13.35 & 24.20 & 37.55 & 66.00 & 0.068 \\
\hline GGISC-7 & 1.51 & 0.85 & 43.46 & 15.35 & 22.15 & 37.50 & 66.00 & 0.065 \\
\hline GGISC-8 & 1.14 & 0.68 & 40.12 & 15.80 & 22.95 & 38.75 & 68.00 & 0.065 \\
\hline GGISC-9 & 1.28 & 0.67 & 47.62 & 13.10 & 19.25 & 32.35 & 66.00 & 0.066 \\
\hline GGISC-10 & 1.46 & 0.77 & 47.44 & 14.20 & 20.20 & 34.40 & 60.00 & 0.066 \\
\hline GGISC-11 & 1.20 & 0.70 & 41.93 & 15.11 & 18.95 & 34.06 & 52.00 & 0.063 \\
\hline GGISC-12 & 1.45 & 0.79 & 45.48 & 17.45 & 22.45 & 39.90 & 56.00 & 0.065 \\
\hline GGISC-13 & 1.24 & 0.72 & 41.79 & 16.25 & 23.45 & 39.70 & 67.34 & 0.065 \\
\hline GGISC-14 & 1.70 & 1.03 & 39.26 & 12.80 & 21.50 & 34.30 & 68.00 & 0.064 \\
\hline GGISC-15 & 1.37 & 0.79 & 42.18 & 14.55 & 22.00 & 36.55 & 69.38 & 0.066 \\
\hline GGISC-16 & 1.41 & 0.78 & 44.36 & 18.35 & 24.85 & 43.20 & 70.00 & 0.065 \\
\hline GGISC-17 & 1.41 & 0.77 & 45.34 & 13.3 & 19.15 & 32.45 & 64.00 & 0.065 \\
\hline GGISC-18 & 1.43 & 0.75 & 47.39 & 13.75 & 24.15 & 37.90 & 68.00 & 0.066 \\
\hline GGISC-19 & 1.87 & 1.03 & 44.80 & 13.95 & 20.70 & 34.65 & 61.22 & 0.066 \\
\hline GGISC-20 & 1.21 & 0.70 & 42.14 & 18.55 & 24.90 & 43.45 & 62.00 & 0.065 \\
\hline GGISC-21 & 1.26 & 0.96 & 23.90 & 12.84 & 17.56 & 30.40 & 20.00 & 0.049 \\
\hline GGISC-22 & 1.28 & 0.73 & 43.24 & 14.35 & 23.90 & 38.25 & 59.18 & 0.065 \\
\hline GGISC-23 & 1.15 & 0.71 & 37.99 & 13.05 & 22.20 & 35.25 & 68.00 & 0.064 \\
\hline GGISC-24 & 1.53 & 0.88 & 42.75 & 14.20 & 23.05 & 37.25 & 69.39 & 0.065 \\
\hline GGISC-25 & 2.00 & 1.11 & 44.53 & 17.40 & 23.80 & 41.20 & 68.75 & 0.067 \\
\hline GGISC-26 & 1.67 & 0.92 & 44.91 & 18.30 & 24.25 & 42.55 & 66.00 & 0.065 \\
\hline GGISC-27 & 1.66 & 0.91 & 45.28 & 14.10 & 20.75 & 34.85 & 58.00 & 0.065 \\
\hline GGISC-28 & 1.58 & 0.90 & 42.85 & 13.90 & 21.25 & 35.15 & 64.00 & 0.064 \\
\hline GGISC-29 & 2.05 & 1.11 & 46.05 & 15.85 & 22.35 & 38.20 & 72.00 & 0.067 \\
\hline GGISC-30 & 1.95 & 1.10 & 43.40 & 13.10 & 18.80 & 31.90 & 70.00 & 0.066 \\
\hline GGISC-31 & 2.01 & 1.05 & 47.84 & 14.00 & 18.97 & 32.97 & 62.00 & 0.065 \\
\hline GGISC-32 & 1.76 & 0.93 & 47.44 & 14.65 & 19.19 & 33.84 & 64.58 & 0.065 \\
\hline GGISC-33 & 2.02 & 1.10 & 45.62 & 13.65 & 18.60 & 32.25 & 62.00 & 0.067 \\
\hline GGISC-34 & 1.80 & 0.94 & 48.02 & 15.00 & 20.00 & 35.00 & 60.00 & 0.066 \\
\hline GGISC-35 & 2.01 & 1.05 & 47.62 & 16.05 & 21.3 & 37.35 & 69.39 & 0.066 \\
\hline GGISC-36 & 1.92 & 1.08 & 43.80 & 14.45 & 19.00 & 33.45 & 74.47 & 0.066 \\
\hline GGISC-37 & 2.15 & 0.98 & 54.22 & 16.90 & 21.45 & 38.35 & 60.00 & 0.065 \\
\hline GGISC-38 & 2.08 & 1.12 & 45.98 & 14.80 & 19.50 & 34.30 & 68.00 & 0.066 \\
\hline GGISC-39 & 1.76 & 1.01 & 42.73 & 12.70 & 19.00 & 31.70 & 60.00 & 0.065 \\
\hline GGISC-40 & 1.87 & 1.10 & 41.17 & 13.41 & 18.90 & 32.31 & 62.00 & 0.065 \\
\hline GGISC-41 & 1.35 & 0.83 & 38.25 & 13.70 & 18.95 & 32.65 & 70.00 & 0.065 \\
\hline GGISC-42 & 1.97 & 1.09 & 44.45 & 14.30 & 19.90 & 34.20 & 68.00 & 0.065 \\
\hline GGISC-43 & 1.64 & 0.89 & 45.54 & 14.80 & 18.70 & 33.50 & 64.00 & 0.064 \\
\hline GGISC-44 & 1.64 & 0.95 & 41.96 & 15.25 & 19.25 & 34.50 & 68.75 & 0.066 \\
\hline GGISC-45 & 1.62 & 0.89 & 45.06 & 13.75 & 18.90 & 32.65 & 58.00 & 0.065 \\
\hline GGISC-46 & 1.68 & 0.89 & 46.76 & 15.20 & 18.85 & 34.05 & 60.00 & 0.066 \\
\hline GGISC-47 & 1.74 & 0.99 & 43.05 & 13.65 & 19.99 & 33.64 & 61.22 & 0.066 \\
\hline GGISC-48 & 1.43 & 0.81 & 43.27 & 14.80 & 20.30 & 35.10 & 64.00 & 0.065 \\
\hline
\end{tabular}

Table 1: Continue... 
Host Plant Resistance for Bruchids in Pre-breeding Lines of Greengram [Vigna radiata (L.) Wilczek]

Table 1: Continue...

\begin{tabular}{|c|c|c|c|c|c|c|c|c|}
\hline GGISC-49 & 1.51 & 1.18 & 21.80 & 12.15 & 17.22 & 29.37 & 14.00 & 0.048 \\
\hline GGISC-50 & 1.77 & 1.10 & 37.80 & 13.79 & 19.85 & 33.64 & 68.09 & 0.067 \\
\hline GGISC-51 & 1.42 & 0.79 & 44.41 & 14.35 & 19.55 & 33.90 & 62.00 & 0.066 \\
\hline GGISC-52 & 1.64 & 0.80 & 51.16 & 18.15 & 22.60 & 40.75 & 66.00 & 0.068 \\
\hline GGISC-53 & 1.74 & 0.93 & 46.73 & 16.25 & 21.95 & 38.20 & 68.00 & 0.067 \\
\hline Mean & 1.61 & 0.91 & 43.170 & 14.72 & 20.93 & 35.65 & 61.50 & 0.064 \\
\hline Range & $1.14-2.15$ & $0.67-1.18$ & $21.8-54.22$ & $12.15-18.55$ & $17.22-24.90$ & $29.37-43.45$ & $14.00-74.47$ & $0.048-0.068$ \\
\hline SE & 0,037 & 0.019 & 0.807 & 0.219 & 0.284 & 0.453 & 1.698 & 0.003 \\
\hline$C D(P=05)$ & 0.104 & 0.053 & 0.425 & 0.754 & 0.910 & 1.505 & 4.575 & 0.014 \\
\hline VBN $(\mathrm{Gg}) 2$ & 1.63 & 0.69 & 57.53 & 18.80 & 26.55 & 45.35 & 100.00 & 0.078 \\
\hline $\begin{array}{l}\text { Vigna radiata } \\
\text { var. sublobata }\end{array}$ & 0.65 & 0.53 & 18.60 & 11.02 & 15.34 & 26.36 & 12.00 & 0.044 \\
\hline
\end{tabular}

Note: Parental lines were not included in statistical analysis.

Table 2: Bruchid screening of parents and resistant lines for confirmation.

\begin{tabular}{|c|c|c|c|c|c|c|c|c|}
\hline Genotypes & $\begin{array}{l}\text { Initial seed } \\
\text { weight } \\
\text { (g) }\end{array}$ & $\begin{array}{c}\text { Final seed } \\
\text { weight } \\
\text { (g) }\end{array}$ & $\begin{array}{l}\text { Weight loss } \\
\text { per cent } \\
\text { of seed }\end{array}$ & $\begin{array}{c}\text { Male bruchid } \\
\text { weight } \\
(\mathrm{mg})\end{array}$ & $\begin{array}{c}\text { Female } \\
\text { bruchid weight } \\
(\mathrm{mg})\end{array}$ & $\begin{array}{c}\text { Total bruchid } \\
\text { weight } \\
\text { (mg) }\end{array}$ & $\begin{array}{c}\text { Seed damage } \\
\text { per cent } \\
\text { on } 30^{\text {th }} \text { day }\end{array}$ & $\begin{array}{c}\text { Susceptibility } \\
\text { index }\end{array}$ \\
\hline GGISC-2 & 1.17 & 0.89 & 23.20 & 12.61 & 17.73 & 30.34 & 20.00 & 0.049 \\
\hline GGISC-21 & 1.29 & 0.97 & 24.72 & 13.01 & 17.12 & 30.13 & 18.00 & 0.048 \\
\hline GGISC-49 & 1.55 & 1.21 & 21.46 & 12.33 & 16.64 & 28.97 & 16.00 & 0.048 \\
\hline VBN $(G g) 2$ & 1.68 & 0.74 & 55.60 & 19.45 & 24.7 & 44.15 & 100.00 & 0.079 \\
\hline $\begin{array}{l}\text { Vigna radiata } \\
\text { var. sublobata }\end{array}$ & 0.67 & 0.54 & 18.91 & 11.21 & 15.92 & 27.13 & 8.00 & 0.042 \\
\hline
\end{tabular}

Table 3: Categorization of 53 inter sub-specific lines based on the seed damage per cent on $30^{\text {th }}$ day of screening (cumulative).

\begin{tabular}{lcl}
\hline Class & Seed damage per cent & Genotypes \\
\hline Highly resistant & $0-10$ & - \\
Resistant & $10.1-20$ & GGISC-2, GGISC-21, GGISC-49, Vigna radiatavar. sublobata \\
Moderately resistant & $20.1-40$ & GGISC-4 \\
Susceptible & GGISC-1, GGISC-3, GGISC-5, GGISC-6, GGISC-7, GGIAC-8, GGISC-9, GGISC-10, \\
& & GGISC-11, GGISC-12, GGISC-13, GGISC-14, GGISC-15, GGISC-16, GGISC-17, \\
& & GGISC-18, GGISC-19, GGISC-20, GGISC-22, GGISC-23, GGISC-24, GGISC-25, \\
& GGISC-26, GGISC-27, GGISC-28, GGISC-29, GGISC-30, GGISC-31, GGISC-32, \\
& GGISC-33, GGISC-34, GGISC-35, GGISC-36, GGISC-38, GGISC-39 GGISC-40, \\
Highly susceptible & GGISC-41, GGISC-42, GGISC-43, GGISC-44, GGISC-45, GGISC-46, GGISC-47, \\
\hline
\end{tabular}

The three lines viz., GGISC-2, GGISC-21 and GGISC-49 recorded less than 20 per cent seed damage and less than 40 per cent damage on $40^{\text {th }}$ day of screening (data not shown) and classified as resistant. Apart from this, one line showed moderately resistant category and 49 lines fall under susceptible category (Table 1) (Fig 1).

\section{Confirmation screening}

Confirmation screening was carried out for three lines of greengram (GGISC-2, GGISC-21 and GGISC-49) that were found resistant during initial screening, along with the parental lines (VBN $(\mathrm{Gg}) 2$ and Vigna radiata var. sublobata). All the observations were recorded during 30 days of screening and obtained data was statistically analysed and damage assessment was carried out. Concurrent and promising results were obtained during confirmation screening. All the three inter sub specific lines (GGISC-2, GGISC-21, GGISC-49) and Vigna radiata var. sublobata were found to be resistant for bruchid damage (Table 2).

Three resistant lines of greengram viz., GGISC-2, GGISC-21, GGISC-49 and Vigna radiata var. sublobata showed prolonged developmental period and there was no peak emergence of bruchid during both initial and confirmation screening. There was an erratic and uneven pattern of adult emergence indicating the presence of resistance against bruchid infestation. Days to first adult emergence was prolonged in resistant lines compared to the susceptible lines. However, all the three resistant lines 


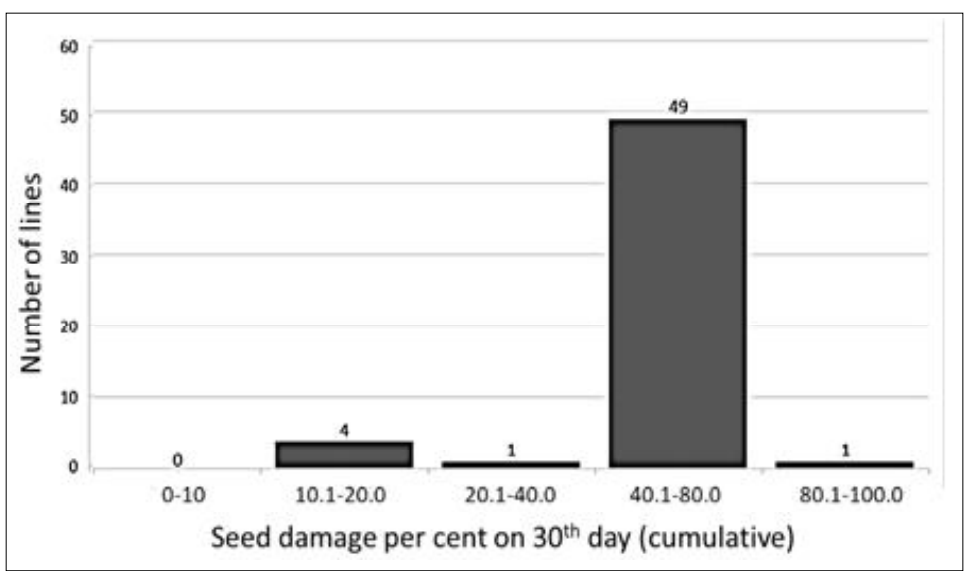

Fig 1: Frequency distribution of seed damage per cent on $30^{\text {th }}$ day (cumulative) for all the 53 inter sub-specific lines of greengram along with the parents.

recorded low hundred seed weight and seed coat colour were not green. Thus, the above lines could not be exploited directly for commercial cultivation. In future, resistance of these lines could be confirmed by using tightly linked molecular markers available for bruchid resistance. The chemical compound responsible for bruchid resistance could also be studied for effective use of these lines as donors for bruchid resistance. Thus, the three resistant lines obtained in the present study can be utilized as a pre-breeding material and could be used as parents in the crossing programme to develop bruchid resistant varieties in greengram.

Conflict of interest: None.

\section{REFERENCES}

Brar, J., Bains, T., Shanmugasundaram, S., Singh, S. (2004). Developing short duration mungbean genotypes suitable for rice-wheat cropping system. Improving Income and Nutrition by Incorporating Mungbean in Cereal Fallows in the Indo-Gangetic Plains of South Asia. 1: 61-81.

Dongre, T., Pawar, S., Harwalkar, M. (1993). Resistance to Callosobruchus maculatus (F.) (Coleoptera: Bruchidae) in pigeonpea [Cajanus cajan (L.) Millsp.] and other Cajanus species. Journal of Stored Products Research. 29: 319-322.

Gosh, S., Roy, A., Kundagraml, S. (2020). Screening of mungbean (Vigna radiata) genotypes against bruchid (Callosobruchus maculatus) attack to reduce postharvest losses. Legume Research. 1: 9-11.

Howe, R. (1971). A parameter for experssing the suitability of an environment for insect development. Journal of Stored Products Research. 7: 63-65.

Khattak, S., Hamed, M., Khatoon, R., Mohammad, T. (1987). Relative susceptibility of different mungbean varieties to Callosobruchus maculatus F.(Coleoptera: Bruchidae). Journal of Stored Products Research. 23: 139-142.

Mariammal, I., Seram, D., Samyuktha, S.M., Karthikeyan, A., Dhasarathan, M., et al. (2019). QTL mapping in Vigna radiata $\mathrm{x}$ Vigna umbellata population uncovers major genomic regions associated with bruchid resistance. Molecular Breeding. 39: 110-122.
Mei, L., Cheng, X., Wang, S., Wang, L., Liu, C., Sun, L., Xu, N., Humphry, M., Lambrides, C., Li, H. (2009). Relationship between bruchid resistance and seed mass in mungbean based on QTL analysis. Genome. 52: 589-596.

Mookherjee, P., Jotwani, M., Yadav, T., Sircar, P. (1970). Studies on incidence and extent of damage due to insect pests in stored seeds-II. Leguminous and vegetable seeds. Indian Journal of Entomology. 32: 350-355.

Nagaraja, M. (2006). Evaluation of pigeonpea and cowpea genotypes for bruchid resistance (Bruchidae). M. Sc. (Agri.) Thesis, UAS, Dharwad.

Neupane, S., Subedi, S., Thapa, R.B., Gc, Y.D., Pokheral, S. (2016). Development of the pulse beetle (Callosobruchus chinensis L.) and ovipositional preference on different legumes under storage. The Journal of Agriculture and Environment. 17: 131-140.

Samyuktha, S., Venugopal, S., Karthikeyan, A., Vanniarajan, C., Senthil, N., Hepziba, S., Malarvizhi, D. (2020). Vulnerability of popular mungbean varieties of South India to the predominant pulse storage pest, Callosobruchus maculatus (F.). Journal of Entomology and Zoology Studies. 8: 146-151.

Sarkar, S. and Bhattacharyya, S. (2015). Screening of greengram genotypes for Bruchid (Callosobruchus chinensis L.) resistance and selection of parental lines for hybridization programme. Legume Research. 38: 704-706.

Soumia, P., Srivastava, C., Dikshit, H., Pandi, G. (2017). Screening for resistance against pulse beetle, Callosobruchus analis (F.) in greengram [Vigna radiata (L.) Wilczek] accessions. Proceedings of the National Academy of Sciences, India Section B: Biological Sciences. 87: 551-558.

Sutanu, S. and Somnath, B. (2015). Screening of greengram genotypes for Bruchid (Callosobruchus chinensis L.) resistance and selection of parental lines for hybridization programme. Legume Research. 38: 704-706.

Zaid, I., Khalil, I., Khan, S. (2012). Genetic variability and correlation analysis for yield components in mungbean [Vigna radiata (L.) Wilczek]. Journal of Agricultural and Biological Science. 7: 885-891. 